Canadian University Music Review

Revue de musique des universités canadiennes

\author{
Jane Girdham. English Opera in Late Eighteenth-Century \\ London: Stephen Storace at Drury Lane. Oxford: Clarendon \\ Press, 1997. xiv, 272 pp. ISBN 0-19-816254-5 (hardcover)
}

\title{
Pauline Minevich
}

Volume 20, numéro 1, 1999

URI : https://id.erudit.org/iderudit/1015655ar

DOI : https://doi.org/10.7202/1015655ar

Aller au sommaire du numéro

Éditeur(s)

Canadian University Music Society / Société de musique des universités canadiennes

ISSN

0710-0353 (imprimé)

2291-2436 (numérique)

Découvrir la revue

Citer ce compte rendu

Minevich, P. (1999). Compte rendu de [Jane Girdham. English Opera in Late Eighteenth-Century London: Stephen Storace at Drury Lane. Oxford: Clarendon Press, 1997. xiv, 272 pp. ISBN 0-19-816254-5 (hardcover)]. Canadian University Music Review / Revue de musique des universités canadiennes, 20(1), 126-130. https://doi.org/10.7202/1015655ar

All Rights Reserved (c Canadian University Music Society / Société de musique des universités canadiennes, 2000
Ce document est protégé par la loi sur le droit d'auteur. L'utilisation des services d'Érudit (y compris la reproduction) est assujettie à sa politique d'utilisation que vous pouvez consulter en ligne.

https://apropos.erudit.org/fr/usagers/politique-dutilisation/ 
Jane Girdham. English Opera in Late Eighteenth-Century London: Stephen Storace at Drury Lane. Oxford: Clarendon Press, 1997. xiv, 272 pp. ISBN 0-19-816254-5 (hardcover).

Throughout the eighteenth century, Londoners enjoyed rich and varied theatrical fare. The King's Theatre in the Haymarket presented Italian opera on Tuesdays and Saturdays, while the two Theatres Royal, Drury Lane and Covent Garden, were open six days a week from September until June, and presented mixed bills of plays, musicals of various kinds, and English opera. The evening's entertainment at the latter theatres consisted of a mainpiece and an afterpiece, interspersed with music, singing, dancing, and other musical entertainment. The popularity of English opera has traditionally been understated, thus it may surprise the reader to know that in the period from 1776 to the end of the eighteenth century, of the twelve most performed mainpieces in the London theatres, six were English operas, as were the top nine of the twelve most popular afterpieces. ${ }^{1}$ Until now, the theatrical history of the eighteenth century has been written largely by literary historians, and their work has not reflected the importance of music in the London theatres. For example, the standard reference work on eighteenth-century theatre, The London Stage, has a 218-page introduction to Part 5, 1776-1800, in which there is virtually no mention of the popularity of opera, or of composers, singers, or musicians in the theatres. It is refreshing, therefore, to see this balance redressed through Jane Girdham's book.

That said, the content of this book does not entirely reflect its title. While undoubtedly important in the context of theatrical music, and of music at Drury Lane in particular, Storace was only one of many composers working in London in the last quarter of the eighteenth century. One cannot attempt a comprehensive history such as English Opera in Late Eighteenth-Century London implies, without some discussion of the works of other prolific composers of the period, such as Samuel Arnold, Charles Dibdin, the Linleys, and William Shield, among others. William Shield was the house composer at Covent Garden from 1784 until 1797, and wrote over twenty-five operatic works during that period. ${ }^{2}$ Samuel Arnold composed for the Little Theatre in the Haymarket for twenty-five years, beginning in 1777, and wrote, or contributed to, over seventy operas. ${ }^{3}$ Their contribution to the sheer volume of English operas in the last twenty years of the eighteenth century was tremendous, and the popularity of their works is clear by the number of performances they received. Two of Arnold's operas, The Spanish Barber (Little Theatre, 1777) and Inkle and Yarico (Little Theatre, 1787) received together 306 performances between 1777 and 1800; Shield's afterpiece opera Rosina (Covent Garden,

1 Charles Beecher Hogan, The London Stage, 1776-1800: A Critical Introduction (Carbondale: Southern Illinois University Press, 1968), clxxi. The operas were (composer and number of performances in parentheses): The Beggar's Opera (Thomas Arne, 229), Love in a Village (Thomas Arne, 168), The Duenna (Thomas Linley Sr. and Jr., 164), Inkle and Yarico (Samuel Arnold, 164), The Spanish Barber (Samuel Arnold, 142), and The Haunted Tower (Stephen Storace, 112).

2 The New Grove Dictionary of Opera, s.v. "Shield, William," by Linda V. Troost.

3 Ibid., s.v. "Arnold, Samuel," by Robert Hoskins. 
1782) was performed 201 times in the same period. The statistics are even more impressive when we consider performances of afterpieces. I noted above that the first nine most performed afterpieces were all operas. Three were by Shield, with a total of 501 performances, and four were by Arnold, with an astounding total of 683 performances. ${ }^{4}$

It is reasonable to expect, then, that a book entitled English Opera in Late Eighteenth-Century London would contain a substantial discussion of at least some of the other composers working alongside Storace. But Girdham confines herself to one sentence dealing with their activities: "The other theatres also had house composers: William Shield worked at Covent Garden in the last decades of the century, and Samuel Arnold wrote the majority of new musical works for the Little Theatre in the 1790s" (p. 79). There is also a brief and general comparison of Storace's works with those of his English contemporaries ("Storace in Context," 131-35). I think that this is hardly comprehensive enough to justify the book's main title, and indeed could cause problems. There are few reference works on eighteenth-century English opera, and the casual reader might well be led, from reading this book, to the incorrect assumption that Storace was the only notable composer of the period. Girdham's doctoral dissertation was entitled "Stephen Storace and the English Opera Tradition of the Late Eighteenth Century," and this title would seem more appropriate for the present book, whose main subject is the life and works of Stephen Storace (1762-96), with special emphasis on the operas he wrote for Drury Lane.

The book is divided into two sections, "Contexts" and "The Music" (meaning Storace's music). Girdham begins with a biography of Storace. The son of an Italian musician who had emigrated to London around 1750, Storace was sent by his father to train at the San Onofrio conservatory in Naples. Storace travelled around Europe for a while, returning to London in the 1780s. His sister Nancy, a very fine coloratura soprano, was engaged as prima buffa at the Burgtheater in Vienna in 1783, and obtained commissions from the Emperor for two operas from Stephen, Gli sposi malcontenti (Burgtheater, 1785), and Gli equivoci (Burgtheater, 1786). Nancy was associated with Mozart (she created the role of Susanna in Le nozze di Figaro), and through her, Storace and Mozart became friends. It is evident in his Italian operas that Storace was much influenced by Mozart's compositional style. Nancy returned to England in 1787, and she and Stephen worked for a while in Italian opera at the King's Theatre, she as a prima buffa and he as a music director, but they were soon ousted by the clique running King's. With a family to support, Storace turned perforce to writing English opera for Drury Lane, with Nancy as his principal singer. Here he bowed to audience taste and spent the rest of his short life writing operas in English with spoken dialogue.

The other three chapters that comprise the first section of the book deal with theatrical life of the time; musicians at Drury Lane; and music publishing in

\footnotetext{
4Hogan, The London Stage, clxxi. The operas were: by Shield, Rosina, The Poor Soldier (Covent Garden, 1783), and The Flitch of Bacon (Little Theatre, 1778); by Arnold, The Agreeable Surprise (1781), The Son-in-Law (1779), Peeping Tom of Coventry (1784), and The Children in the Wood (1793). Arnold's operas were all written for the Little Theatre.
} 
the eighteenth century. Here again, I feel that the book is lacking a discussion of the development of English opera earlier in the century, and of Storace's contemporaries. In her introduction Girdham refers to "the traditional forms of English opera" (p. 3), but there is no attempt at definition or contextualization until p. 123, "Questions of Genre." The chapter on theatrical life mostly contains information that is already available in literary histories of the eighteenth-century stage, but it is useful to have a condensed version in which special attention is given to musical matters. Girdham's writing style here, as throughout the book, is clear and concise.

Chapter 4, on musicians at Drury Lane, contains much new information, painstakingly collected from Drury Lane Paybooks for 1788-96, and from the theatrical diaries of John Kemble, the manager of Drury Lane during this period. Details of the names, salaries, and numbers of musicians employed at Drury Lane earlier in the century are very sketchy, but fortunately Kemble kept detailed accounts, and this information is presented here for the first time. While several books have been written on the musicians, singers, and composers of Italian opera in late eighteenth-century London, little has been produced about their counterparts in the English language theatre, and Girdham's work here is most useful. Kemble kept a list of the members of the orchestra for the 1791-92 and 1794-95 seasons, and according to his notes, the pit orchestra was sometimes divided into "day bands" and "half bands." Girdham speculates that "day bands," which were groups of four or five musicians, could have been used either to sketch the accompaniment for rehearsals, or possibly to play on evenings where there was little music in the performance. While I can accept the latter possibility for half bands, I think it highly unlikely that a small group such as a day band would have been used for a performance. For the 1791-92 season, the Drury Lane company used the King's Theatre, with a seating capacity of over 3,000 , while in 1794 it returned to its own theatre, newly rebuilt, with over 3,600 seats. It is difficult to imagine that a band of four or five people would be acceptable for any public performance in either of these two large auditoriums.

The chapter on music publishing also offers original research and information. In 1777, Johann Christian Bach won a lawsuit against the publisher James Longman for unauthorized publication of two of his compositions (p. 88), and music was declared subject to the Copyright Act. Composers began to register their work at Stationers' Hall, and this is the source of much of Girdham's information. Her statement that "English operas were never published ... as orchestral scores or parts" (p. 83) begs correction, since there are some obvious exceptions, such as The Fairies and The Tempest (David Garrick and John Christopher Smith, 1755 and 1756 respectively), and The Lord of the Manor (General John Burgoyne and William Jackson, 1780). While her statement may be true for the last fifteen years of the eighteenth century, it would be more accurate to say that English operas were rarely published as orchestral scores or parts.

The second part of the book is devoted entirely to Stephen Storace's works. Chapter 5 is a discussion of genre, always a difficult question when dealing with English opera. By Storace's time, it had become clear that the Drury Lane 
and Covent Garden audiences would not tolerate sung recitative; thus the accepted format for English opera in this period was one of overture, arias, and ensembles, interspersed with spoken dialogue. The dilemma, then, is how to distinguish between an opera per se, and a spoken play with a lot of music; as Linda Troost has written in a discussion of the comic operas of Isaac Bickerstaff and Thomas Arne, "Bickerstaff, the father of the genre [of comic opera] ... wrote works that look like straight plays with songs tipped in."5 Girdham provides two criteria to aid in forming this distinction:

The first criterion for whether a work is an opera is its use of music at structurally significant moments. An opera always opens with an overture ... It also ends with a vocal ensemble, and a variety of vocal numbers are performed in the course of the drama. In other words, music provides a structural framework and is dispersed throughout the spoken dialogue. (p. 131)

This is not much of an advance on the time-honoured system of defining an opera as a two- or three-act work with an overture, while a play has five acts and a prologue. The Beggar's Opera, for instance, meets Girdham's criterion, yet is undoubtedly a play with music.

Her second criterion is presented "to distinguish opera from the profusion of English plays with music, and from genres in which music plays a different function, such as the masque. The majority of the main dramatic roles should be played by the principal singers" (p. 132). This interesting idea has not, to my knowledge, been advanced before, and makes sense in the context of the Drury Lane and Covent Garden companies. Both companies kept lists of their employees, and in each case, singers were listed separately from actors or actresses. Charles Burney described Nancy Storace, for instance, as "a lively and intelligent actress,"6 but she was listed at Drury Lane as a singer, and it is quite true that anything in which she sang a principal role would be understood by the audience as an opera. Girdham's criterion would also clarify the genre of some earlier works, for example, David Garrick's Cymon (Drury Lane, 1767; music by Michael Arne). Garrick subtitled it a "dramatic romance," and despite containing some twenty-six musical numbers, it has usually been termed a play with music, since it has a prologue as well as an overture, and is in five acts. But the two principal roles were taken by the singers Elizabeth Arne and Joseph Vernon, so using Girdham's criterion, one could term it an opera. Interestingly, this work was revived in a large-scale production at Drury Lane in 1791, on which occasion it was advertised as "First performed as an Opera." The only significant change from the 1767 version was the addition of a few new numbers, some of them written by Storace.?

5Linda Veronika Troost, "The Rise of English Opera, 1760-1800" (Ph.D. diss., University of Pennsylvania, 1985), 28.

6The New Grove Dictionary of Opera, s.v. "Storace, Nancy," by Patricia Lewy Gidwitz and Betty Matthews.

7David Garrick, David Garrick's Cymon, a Dramatic Romance. First performed as an Opera, in Five Acts, by His Majesty's Company, from the Theatre-Royal, Drury Lane, in the King's Theatre in the Haymarket, on Saturday, December 31, 1791 (London: T. Becket, 1792). 
The remainder of the book is an analysis and assessment of some of Storace's better-known English operas, in chapters on mainpieces, afterpieces, and borrowings. Chapter 6, on mainpieces, concentrates on The Haunted Tower (1789) and The Pirates (1792). In each case, Girdham outlines the circumstances of composition, briefly mentions critical and audience reaction, and provides a synopsis. The music of each opera receives a thorough and illuminating discussion, but I find the frequent references to "typically English" procedures annoying, since these are neither clearly defined nor supported with examples. For instance, discussing Storace's act finales in The Pirates, she says "They differ greatly from the typical English finale, which is in one section, visually spectacular rather than dramatic, and performed after the action has been completed in spoken dialogue," but no example is cited to support the statement.

The most interesting chapter of the book concerns Storace's borrowings. Many, if not most, English operas of the late eighteenth century were constructed as pasticcios, or, to use the English expression, pastiches. In other words, the composer would borrow a large proportion of the musical numbers from the works of other composers, sometimes wholesale, sometimes reworking and adapting the borrowed material. William Shield and Samuel Arnold usually incorporated traditional British folksongs or borrowed the works of other (often earlier) English composers, but Storace's borrowings tended to be from other buffa composers, such as Paisiello, Martín y Soler, and Salieri, or from his own earlier Italian operas. (His borrowings are fully documented in an appendix.) Sometimes he added original material within a borrowed number, and Girdham makes the valid point that the way he incorporated and adapted borrowings is one of his strengths as a composer. She gives many examples of the way Storace altered and extended pre-existent finales to make them more dramatically and musically effective, and points out that in this respect, his music owes much to Italian opera buffa traditions, and in particular to Mozart's example. As she says, this is certainly Storace's greatest legacy to English opera, but she asserts that "although his achievements were recognized by contemporary critics, he had disappointingly little influence on his colleagues and successors" (p. 135). Although his contemporaries did not follow his adoption of a Mozartean musical style, there is evidence that they did follow his example of integrating music and drama in English opera. For instance, Robert Hoskins says in his article for The New Grove Dictionary of Opera on Samuel Arnold, "Of special interest are the ensembles [of Arnold's later operas], which often show that Arnold clearly understood the nature of music drama and was moved to match dramatic event with musical gesture." Similarly, Linda Troost writes of William Shield's The Woodman (1791), "critics noted that music now had the primary, not the secondary, role, as was the case in works at Drury Lane."

Overall, Girdham's book shows evidence of thorough and painstaking research, which is carefully organized and presented. Her style is clear, concise, and eminently readable. Taken as a study of the work of Stephen Storace, rather than as a general history of late eighteenth-century English opera, this is a valuable and welcome addition to the literature. 